\title{
Tindak Tutur Ekspresif Mahasiswa Program Studi PGSD STKIP Setiabudhi Dalam Pembelajaran Apresiasi Sastra Anak
}

\author{
Eka Nurul Mualimah ${ }^{1 *}$, Ade Eka Anggraini ${ }^{2}$, Usmaedi $^{3}$, Elih Solihatulmilah ${ }^{4}$ \\ 1,3,4STKIP Setiabudhi, 2Universitas Negeri Malang \\ *e_frisca@yahoo.com
}

\begin{abstract}
Pragmatics is the study of the meaning conveyed by the speaker (or writer) and interpreted by the listener (or reader). As a result, this study has more to do with the analysis of what people mean by their utterances than with the separate meanings of the words or phrases used in the speech itself. This study aims to describe the expressive speech acts of the 3rd semester students of PGSD STKIP Setiabudhi in learning children's appreciation. The method used is a qualitative descriptive method. In this study, the research sources were the 3rd semester students of PGSD STKIP Setiabudhi using tapping techniques, competent engaging listening techniques, and competing free listening techniques. The results showed that there were 5 types and variants of expressive speech functions including 'thanking', 'apologizing', 'insinuating', 'saying goodbye', and 'complaining'. Thus, students' expressive speech acts in learning children's appreciation had characteristics such as Rymes' theory by considering and paying attention to the social context, the international context and the individual agency context.
\end{abstract}

Keywords: Acting Speech and Expressive Speech

\section{ABSTRAK}

Pragmatik adalah studi tentang makna yang disampaikan oleh penutur (atau penulis) dan ditafsirkan oleh pendengar (atau pembaca). Sebagai akibat studi ini lebih banyak berhubungan dengan analisis tentang apa yang dimaksudkan orang dengan tuturan-tuturannya daripada dengan makna terpisah dari kata atau frasa yang digunakan dalam tuturan itu sendiri. Penelitian ini bertujuan untuk mendeskripsikan tindak tutur ekspresif mahasiswa semester 3 PGSD STKIP Setiabudhi dalam pembelajaran apresiasi anak. Metode yang digunakan adalah metode deskriptif kualitatif. Dalam penelitian ini yang menjadi sumber penelitian adalah Mahasiswa semester 3 PGSD STKIP Setiabudhi dengan menggunakan teknik sadap, teknik simak libat cakap, dan teknik simak bebas libat cakap. Hasil penelitian adalah terdapat 5 jenis dan varian fungsi tutur ekspresif meliputi 'berterima kasih', 'meminta maaf', 'menyindir', 'mengucap selamat', dan 'mengeluh'.Dengan demikian, tindak tutur ekresif Mahasiswa dalam pembelajaran apresiasi anak memiliki karakteristik seperti teori Rymes dengan mempertimbangkan dan memperhatikan konteks social, konteks internasional dan konteks individu agency.

Kata Kunci: Tindak Tutur dan tuturan Ekspresif

Submitted Feb 16, 2021 | Revised Feb 28, 2021 | Accepted Mar 06, 2021

\section{Pendahuluan}

Tindakan manusia ketika mengucapkan tuturan atau ujaran disebut dengan tindak tutur. Dalam berkomunikasi manusia menggunakan tuturan-tuturan untuk mengutarakan apa yang ingin disampaikan, karena itu tindak tutur sangat penting dalam berkomunikasi (Sari, 2012; Muktadir, 2016; Merdian et al., 2018).

Dalam kehidupan sehari-hari, manusia menggunakan bahasa sebagai alat komunikasi. Bahasa yang digunakan itu pun berbeda - beda ragamnya, bergantung situasi, penutur, dan mitra tutur. Situasi dalam tuturan dapat berupa situasi santai dan dapat juga situasi resmi. Penutur dan mitra tutur dapat dilihat dari status, usia, dan jenis kelamin.Tuturan - tuturan yang dihasilkan manusia dalam berkomunikasi dapat diamati dan diteliti (Defina, 2018).

Tuturan biasa digunakan dalam proses komunikasi. Dalam berkomunikasi terdapat minimal seorang penutur dan seorang mitra tutur. Penutur ialah orang yang menyampaikan gagasan, informasi, 
pikiran, dan maksud tertentu. Sedangkan mitra tutur yaitu orang yang menjadi sasaran penutur dalam memahami tuturannya. Tuturan dapat diekspresikan melalui media massa, baik tulisan ataupun lisan. Media massa yang dapat dimanfaatkan adalah media cetak dan media elektronik. Media cetak dapat berupa surat kabar, majalah, tabloid, dan media elektronik dapat berupa radio dan televisi (Ifatul Mu'awanah, 2020). Pada hakikatnya, komunikasi bukan hanya sekedar penyampaian bahasa melalui kata-kata melainkan selalu disertai dengan perilaku atau tindakan sebagai produk atau hasil dari kata atau kalimat yang berwujud perilaku tindak tutur (Murti \& Nurhuda, 2019; Thamimi \& Wiranty, 2019).

Pada tuturan terdapat maksud sebenarnya yang hanya dapat diidentifikasi melalui situasi tutur yang mendukungnya. Leech (1983) berpendapat bahwa situasi tutur itu mencakupi lima komponen. Kelima komponen situasi tutur itu adalah penutur dan mitra tutur, konteks tuturan, tujuan tuturan, tindak tutur sebagai bentuk tindakan atau aktivitas, dan tuturan sebagai produk tindak verbal. Oleh Searle (1969) Tindak tutur yang tak terhitung jumlahnya dikelompokkan menjadi lima jenis sebagai berikut: representatif, direktif, ekspresif, komisitif, dan deklaratif. Tindak tutur ekspresif adalah tindak tutur yang dimaksudkan penuturnya agar ujarannya diartikan sebagai evaluasi tentang hal yang disebutkan dalam tuturan itu. Freaser (1978) menyebut tindak tutur ekspresif dengan istilah evaluatif. Tuturan-tuturan memuji, mengucapkan terima kasih, mengkritik, mengeluh, menyalahkan, mengucapkan selamat, menyanjung, termasuk ke dalam jenis tindak tutur ekspresif ini (Rustono, 1999).

Searle dalam bukunya Speech Acts. An Essay in The Philosophy of Language (Rohmadi, 2004) mengemukakan bahwa secara pragmatis setidak-tidanyaknya ada tiga jenis tindakan yang dapat diwujudkan oleh seorang penutur, yaitu: lokusi, ilokusi dan perlokusi. Tindak tutur lokusi lebih mudah dipahami karena dalam mengidentifikasi tindak tutur ini tidak mempertimbangkan konteks tuturan yang terjadi.

Tindak tutur ilokusi berbeda dengan tindak lokusi, dimana tindak tutur ilokusi maksud penyampaiannya bergantung pada siapa, kapan, dan di mana tuturan tersebut dilakukan, sehingga tuturan ini tidak mudah diidentifikasi begitu saja. Sedangkan Tindak tutur perlokusi adalah tindak tutur yang diutarakan oleh seseorang dan seringkali mempunyai daya pengaruh (perlocution force) atau efek bagi yang mendengarkannya(Wijana, I Dewa Putu, 2009). Efek atau daya pengaruh ini dapat secara sengaja maupun tidak sengaja dikreasikan oleh penuturnya.

Tindak tutur ekspresif dalam kajian ini adalah salah satu bentuk tindak tutur ilokusi, dimana tindak tutur ekspresif dimaksudkan untuk menyatakan atau menunjukkan sikap psikologis penutur terhadap suatu keadaan. Tindak tutur ini mencerminkan pernyataan-pernyataan psikologis dan dapat berupa pernyataan kegembiraan, kesulitan, kesukaan, kebencian, kesenangan, atau kesengsaraan (Yule, 2006).

Tindak tutur ekspresif ini sering di jumpai pada interaksi belajar mengajar dan menarik untuk di kaji. Interaksi belajar mengajar dalam kegiatan pembelajaran adalah proses komunikasi antara pendidik dan peserta didik. Dimana pendidik memiliki cara atau modus tuturan yang menimbulkan efek yang bervariasi. Ketika kegiatan pembelajaran berlangsung tidak hanya sekadar menggunakan bahasa, tetapi juga harus melihat situasi kelas (formal, tidak terlalu formal, atau informal), situasi khusus (faktor psikologis : kognitif, senang, bosan, jengkel, dan sebagainya), maupun aturan-aturan yang berlaku di kelas. Keberadaan tindak tutur dalam kegiatan pembelajaran sangat mempengaruhi perubahan tingkah laku dan aktivitas belajar mulai dari motivasi belajar yang lebih baik, bersemangat maupun efek malu peserta didik (Kushartanti, Yuwana, Untung, 2005).

Kajian tindak tutur ekpsresif ini sangat dibutuhkan dalam kegiatan pembelajaran, dimana produk dari tindak tutur adalah makna atau maksud ujaran. Sebuah tuturan pasti mempunyai maksud tersendiri mengapa tuturan itu terjadi. Penelitian ini memberikan wawasan terhadap pendidik tentang cara atau modus bertutur dan mengetahui efektifan pesan yang disampaikan pendik maupun peserta didik dalam proses pembelajaran. Efektifan pesan yang disampaikan penutur dapat dilihat dari hasil 
atau respon lawan tutur terhadap pesan yang disamapaikan penutur baik yang dilakukan pendidik maupun peserta didik. Adanya respon lawan tutur menunjukan bahwa komunikasi berjalan sesuai maksud ujaran penutur.

\section{Metode Penelitian}

Dalam suatu penelitian sangat dibutuhkan sebuah metode yang berguna untuk memperoleh hasil penelitian yang lebih baik dengan harapan agar hasil penelitiannya bisa lebih objektif lagi. Metode penelitian yang digunakan adalah metode deskriptif kualitatif (Moleong, 2009). Hal ini disebabkan datadata dalam penelitian ini berupa deskripsi tuturan antara penutur dan lawan tutur yang terdapat pada kegiatan pembelajaran apresiasi anak.

Data dalam penelitian ini didapatkan dari hasil observasi ketika pembelajaran matakuliah apresiasi anak. Data observasi berupa segmen-segmen tutur beserta konteksnya yang diindikasikan sebagai tindak tutur ekspresif. Data bersumber dari Mahasiswa semester III Prodi Pendidikan Guru Sekolah Dasar STKIP Setiabudhi Rangkasbitung. Tuturan ekspresif didapatkan dari hasil percakapan selama pembelajaran berlangsung. Teknik simak catat dan teknik rekam adalah teknik penelitian yang digunakan, adapun teknik analisisnya melalui proses pengolahan data yang diawali dari reduksi data, penyajian data dan penarikan kesimpulan.

\section{Hasil dan Pembahasan}

Data yang diperoleh dari hasil observasi ketika pembelajaran apresiasis sastra anak pada mahasiswa Prodi Pendidikan Guru Sekolah Dasar Semester III STKIP Setiabudhi Rangkasbitung di identifikasi dan di analisis. Hasil identifikasi dan analisis penelitian terdapat 5 jenis dan varian fungsi tutur ekspresif meliputi 'berterima kasih', 'meminta maaf, 'menyindir', 'mengucap selamat', dan 'mengeluh'.

Pada kegiatan pembelajaran apresiasi sastra, fungsi tindak tutur ekspresif sering di gunakan Dosen maupun Mahasiswa, hal ini dikarenakan tindak tutur ekspresif menyatakan sesuatu yang dirasakan oleh penutur dan berfungsi untuk menunjukkan sikap psikologis penutur terhadap keadaan yang sedang dialami oleh mitra tutur.

Fitri : Kamu pakai wifi?

Jujun : Ini kode wifinya.

Fitri : Terimakasih ya atas wifinya, memang kuota saya sedang habis.

Jujun : Ya.

Percakapan tersebut merupakan tuturan ekspresif mengucapkan terima kasih antara Fitri dan Jujun yang bertujuan untuk menyampaikan sesuatu atas tindakan bermanfaat yang telah disampaikan oleh Fitri kepada Jujun. Tuturan ekspresif ucapan terima kasih biasanya diucapkan penutur atas pertolongan atau perlakuan baik petutur terhadap dirinya. Hal tersebut bisa juga terjadi karena beberapa faktor di antaranya, dikarenakan mitra tutur atau petuturnya bersedia melakukan apa yang diminta oleh penutur, atau dikarenakan kebaikan hati penutur yang telah memberikan sesuatu kepada petutur atau penutur menghargai atas apa yang telah dilakukan petutur.

$\begin{array}{ll}\text { Yoga } & \text { : Jam berapa ini? (sambil berbisik) } \\ \text { Yuningsih } & \begin{array}{l}\text { : Ibu ini waktunya Ibu Eka Setiawati masuk, maaf jam perkuliahan kita sudah } \\ \text { habis }\end{array} \\ \text { Dosen } & \text { : OK, kita sudahi dan sampai minggu depan. } \\ \text { Tuturan ekspresif mengucapkan maaf terjadi karena beberapa faktor, misalnya karena perasaan }\end{array}$
tidak enak penutur terhadap petutur, perasaan bersalah penutur terhadap petutur, atau bisa karena permintaan petutur. Melakukan sesuatu tindakan dalam mengatakan sesuatu atau tindak tutur yang dibatasi oleh konvensi sosial dan psikologis penutur merupakan ciri dari tuturan ekspresif berupa tuturan mengucapkan maaf. 
Nova

: Kita sudahi persentasi kita kali ini, wassalamualaikumum warahmatullohi wabarakatu

Seluru mahasiswa : Wassalamualaikum warohmatullobi wabarokatu

Tia

: Selamat Nov, isi pptnya bagus sekali

Tuturan Tia termasuk tindak tutur ekpresif memuji. Tuturan ini dilakukan ketika persentasi yang dilakukan Nova sangat baik. Penutur memuji dengan kenyataan yang ada, karena apa yang dilihat sesuai dengan kenyataan. Sesuai dengan pendapat Chaer (2010:29), tuturan ekspresif memuji atau tindak tutur ekspresif memuji merupakan tindak tutur yang terjadi karena beberapa faktor, yakni dikarenakan kondisi dari petutur yang sesuai dengan kenyataan yang ada, karena penutur ingin menyenangkan hati petutur, karena penutur ingin melegakan hati petutur, dan karena penutur ingin merayu petutur atau karena perbuatan terpuji yang dilakukan petutur.

Dosen : Kelompok berapakah hari ini?

Piat M : Kelompok saya bu, tapi ppt dilaptop kakak saya dan dibawa kerja belum sepat saya kirim bu

Dosen : Lha kalian persentasi pakai apa? Berarti hari ini kalian tidak siap? Untuk minggu depan bagi yang akan persentasi mohon dipersipkan sehingga tidak ada alasan apapun!

Tuturan ekpresif ini dilakuan ketika awal pembelajaran dimulai dan kelompok yang akan persentasi belum memiliki kesiapan. Tuturan Dosen termasuk tuturan ekspresif mengeluh karena Dosen ingin mengungkapkan rasa kecewa yang disebabkan Mahasiswa tidak memiliki kesiapan dalam melakukan persentasi dan tidak sesuai dengan harapan. Tuturan bermaksud untuk menegaskan kepada mahasiswa bahwa dosen kecewa dan mencoba mengeluh kepada siswa dengan cara sedikit menyindir.

\section{Kesimpulan}

Hasil penelitian tindak tutur ekpresisf mahasiswa Prodi Pendidikan Guru Sekolah Dasar STKIP Setiabudhi terdapat 5 jenis dan varian fungsi tutur ekspresif meliputi 'berterima kasih', 'meminta maaf, 'menyindir', 'mengucap selamat', dan 'mengeluh'. Tuturan ekspresif berterimakasih berupa tindak tutur berterimakasih dilakukan oleh penutur terhadap mitra tutur karena penutur merasa mendapat sesuatu kebaikan dari mitra tutur. Tuturan ekspresif mengucapkan maaf terjadi karena perasaan tidak enak dan bersalah penutur terhadap petutur, Tuturan ekspresif mengucapkan selamat dilakukan guru untuk mengucapkan selamat kepada siswanya karena telah melakukan perintah sesuai keinginan guru. Sedangkan tuturan ekspresif mengeluh dilakukan oleh guru karena ulah tingkah laku siswa yang membuat guru merasa kesal.

\section{Daftar Pustaka}

Defina. (2018). Tindak Tutur Ekspresif Pada Anak-anak Saat Main Bola Di Lapangan. Jurnal Ranah, $7(1), 69-85$.

Ifatul Mu'awanah, A. P. Y. U. (2020). Analisis Tindak Tutur Ekspresif Dalam Berita Dokter Deteksi Virus Corona Meninggal di Wuhan Pada Saluran Youtube Tribunnews.com. Jurnal Skripta, 6(2), 72-80.

Kushartanti, Yuwana, Untung, L. (2005). Pesona BahasaIndonesia Langkah Awal Memahami Linguistik. Jakarta: Gramedia Pustaka Utama.

Merdian, E., Rahayu, N., \& Djunaidi, B. (2018). Analisis Tindak Tutur Dalam Interaksi Tentara Kodim 0409 Rejang Lebong. Jurnal Ilmiah KORPUS, 2(3), 261-269.

Moleong, L. (2009). Metode Penelitian Kualitatif. Bandung: PT Remaja Rosdakarya. 
Muktadir, A. (2016). Aneka Implikatur Yang Terkandung Dalam Tindak Tutur Novel "Ketika Derita Mengabadikan Cinta". Jurnal PGSD: Jurnal Ilmiah Pendidikan Guru Sekolab Dasar, 9(3), 340-346.

Murti, A. R., \& Nurhuda, Z. (2019). Tindak Tutur Direktif Dalam Novel Susah Sinyal Karya Ika Natassa \& Ernest Prakasa (Kajian Pragmatik). Jurnal Sasindo Unpam, 7(1), 70-93.

Rohmadi, M. (2004). Pragmatik dan Teori Analisis. Yogyakarta: Lingkar Media.

Rustono. (1999). Pokok-Pokok Pragmatik. Semarang: Cv.IKIP Semarang Press.

Wijana, I Dewa Putu, dan M. R. (2009). Analisis Wacana Pragmatik Kajian Teori dan Analisis. Surakarta: Yuma Pustaka.

Sari, F. D. P. (2012). Tindak tutur dan fungsi tuturan ekspresif dalam acara Galau Finite di Metro TV: Suatu kajian pragmatik. Jurnal Skriptorium, 1(2), 1-14.

Thamimi, M., \& Wiranty, W. (2019). Tindak tutur Imperatif Bahasa Melayu Dialek Selimbau Kabupaten Kapuas Hulu (Kajian Pragmatik). Jumal Pendidikan Babasa, 8(1), 155-170.

Yule, G. (2006). Pragmatik. Yogyakarta: Pustaka Pelajar. 